\title{
The Role of China in Influencing Indo-Pak Relations in Contemporary Era
}

\author{
Qian Hongdao \\ Professor in Law, Guanghua Law School, Zhejiang University, China \\ Muhammad Bilawal Khaskheli \\ Doctoral Candidate in Law, Guanghua Law School, \\ Zhejiang University, China \\ Rabia Rasheed \\ Master in International Relations, \\ Department of International Relations, University of Karachi, Pakistan \\ Hamid Mukhtar \\ Post-doctoral Fellow in Law, \\ Guanghua Law School, Zhejiang University, China
}

\begin{abstract}
This paper focuses on analytically viewing the nature of the tragic economic and political relationship among Indian, Pakistan, and China from 1949 to 2000. In addition, it explores how much Indo-Pak relations have been influenced by the Sino-Pak growing ties from the early 1960s. Shift in China's South Asia Policy after Mao and particularly in the post-Cold War settings are the major areas of concern. Furthermore, this study focuses on the transformation in the regional and international relations at the end of the cold war to race out the impact on the regional and bilateral dynamics of the three states: China, India, and Pakistan. Scholars agree in their opinion that the postCold war era can be best described as a period of rapid power transitions. There is considerable debate with regard to the direction and magnitude of this transition. Among these transitions, the most significant of them all is the emerging multiplicity with new power center. In the wake of the modernization drive being pursued by China and India, their focus is to liberalize their economics and the growing pursuit of normalization between India and Pakistan in comparison to Indo-Chinese efforts to accommodate each other. This, therefore, is regarded as a reflection of divergent held by the major players in South Asia.
\end{abstract}

Keywords: China, Indo Pak, Relations, Revolutionary idealism, Cold war. 


\subsection{Introduction}

Since the inception of Pakistan and India (Ganguly, 2002), both countries have been the major cause of concern for each other's foreign and security policies (Buzan \& Segal, 1994). Mutual distrust and confrontational relationship have characterized their bilateral diplomacy since 1947 (Ganguly, 2002). Although there have been period of mutual and cordial working relations in their interaction, the overall climate has been antagonistic and less than normal (Varshney, 2003). There are various schools of thoughts as to why India and Pakistan have remained historically locked in a relationship of distrust and mutual hostility (Mukherjee, 2009). A well-known line of argument traces the roots of antagonism to South Asia's historical legacy, dating back to the period when Islam had challenged "Hinduism's" near monopoly (Rizvi, 1993). An offshoot of this historical legacy explanation in the argument of Congress versus Muslim League, and one nation theory contending the two nations theory, have resulted to ideological non-congruity between Islam Pakistan and secular India (Hilali, 2002; Jalal, 1995; Smith, 2015). Therefore, this is the root cause of the conflict between the states (Rashid, 2008).

Consequently, others have attempted to analyze the relationship on the basis of threat, perceptions, and reference to images. Sister Gupter talked on the images and perception cultivated by the ruling elite of both, on the eve of the partition of India (Pande, 2011; Ray \& Qayum, 2009; Tudor, 2013). Similarly, the colonial legacy left behind in the form of the Kashmir dispute (Chaudhri, 1987; Lamb, 1966; Talbot, 2010), the cause of junagarh and Manaudar, the distribution of river waters (Barua, Kuehl, Miller, \& Moore, 1994), the massacre of people while crossing Pak-India boundary followed by a war in 1948 has to be put into consideration (Forman \& Kedar, 2004; Saini, 2014). The failure of India to recognize and follow the UN resolutions to hold a plebiscite in Jammu and Kashmir are termed as contributory factors to the negative security perceptions of the two States (Hussain, 2015). Whereas others are of the opinion that the particular chronology of India's aggressions against Pakistan (Perkovich, 2002; Tellis, Fair, \& Medby, 2002), in the retrospect left nothing but doubts in the minds of the people of Pakistan concerning the notorious designs. Thus, this resulted in the Fall of East Pakistan (Schofield, 2010).

If a single most dominant characteristic of the relations between Pakistan and India could be identified from 1947 (Ganguly, 2002; Joshi, 1974), the finger would almost involuntarily point to the mistrust and lack of confidence between the two sovereign states. Secondly (Amar, 1990; Douglas \& Wildavsky, 1983), there is no getting away from the reality that external factors played a major role in the Subcontinent. In this context both India and Pakistan become involved without side powers on issues which remained 
essentially bilateral (Fisher, Ury, \& Patton, 2011). Kashmir was internationalized by the two protagonists, to be follow by Pakistan's acceptance of Western-military aid and membership of US-sponsored pact (Rather, 2005; Sisson \& Rose, 1991; Syed, 1969). This move was severely condemned by the India leaders on the premise that it had inducted cold war in the region. Later, however, when Indian defense were found inadequate against the relative Chinese Power, India also made maximum effort to secure external assistance (Gupta, 1998; Lavoy \& Lavoy, 2009). Pakistan reacted to the Western power for making Asia fight against Asian.

China has a long boundary with Pakistan and India (Zhisheng et al., 1990). After the partition of the subcontinent, China still had good relations with Indian. Indian pivotal role as an active member of Non-Aligned Movement (NAM) was highly appreciated by Beijing. On the other hand, Pakistan's induction in USA sponsored military pacts not only worsened its relations with India, but also to some extent its relations with China (Brecher, 1963; Lerski, 1968). In the first decade of Indo-Pak Relations, China maintained a non-interfering policy in Indo-Pak bilateral issues (Siddique, 2014). China enjoyed good relations with India in her first decade of diplomatic relations by signing panchsheel and raising the slogans of Hindi Cheeni Bhai Bhai in 1955 (Norbu, 1997). At the time, China showed less concern on Pakistan's Commitments in south East Asia Treaty organization (SEATO) and central Treaty organization (CENTO) and gave friendly gesture in the Banduing conference about Pakistan (A. H. Syed, 1974). Sino Indian differences on McMahon line (Garver, 1996). Dalai Lama and his associate's political asylum in India on the request of USA was the beginning of the animosity between India and China. This gulf of Sino-India relation became wider in 1962 and ultimately led to war (Thomas, 1981). This was the actual turning point and China became a factor in Indo-Pak relations (Mishra, 2004). After the 1962 Sino Indian war (Garver, 2011), China inclined towards Pakistan to meet Indian required changes (M. Arif \& Mahmood, 2012). On the other hand, USA military aid to India during Sino Indian clash caused threat and lot of concerns for Pakistan. It became the main reason to open up China in 1962 after seeing all pros and cons (Haqqani, 2010; Sachs, Warner, Åslund, \& Fischer, 1995).

In 1970, Sino Pakistan collaboration in the nuclear field further deteriorated not only Indo-Pak relations (Ganguly \& Hagerty, 2012), but also Sino-Indian relations. Nevertheless, China have continued to support peaceful negotiation sentiment of Indo-Pak disputes by underscoring its desire for regional stability (Tellis, 2001). After 1949 (Shambaugh, 2000), China's policy remained not to enter into any military alliance, pacts, and treaties with its friends. However, it supported their course (Hemmer \& Katzenstein, 2002). 
Despite qualitative international change after the end of the Cold war in 1991, and then after the Nuclearization of South Asia, some Pakistani still have unrealistically high expectation of China (Brzezinski, 2012; Rajain, 2005). However, they fail to realize that today's China, which is guided by hardboiled pragmatism, is quite different from Mao's China which was motivated by revolutionary idealism. China at the threshold of $21^{\text {st }}$ century is in big-league competition. It is a much different revolutionary movement across the world. Now China is motivated by pragmatic national interests, where its relations with any country are judged on its own merits without ideological predilections (Dijink, 2002).

\subsection{Pak-China Relation, an All-Weather Friendship: The First Phase 1950-1960s}

The first decade of Sino-Pakistan relation saw increasing contacts at the governmental, professional (Kiernan, 1976), and intellectual levels on both sides. Whereas it remained barren of significant, political, and economic content (Kiernan, 1976). The policy reflected different opinion available. In the situations, the choices among alternatives, the bases, and the trends of PakChina in the 1950s and 60s were also governed by the same conditions. Officially, Pak-China diplomatic relations started in the 1950s, and the ambassador of China and Pakistan formally resumed their assignments in their respective capitals by September and November 1951 (Hussain, Javaid, Sabri, Ilyas, \& Batool, 2014).

Pakistan have served as China's main bridge to the Islamic world, and also played an important role in bridging the communication gap between the PRC and the West, by facilitating U.S. President Richard Nixon's historic visit to China in 1972. The relations between Pakistan and China have been described by Pakistan's ambassador to China as "higher than the mountains, deeper than the oceans, stronger than steel, dearer than eyesight, sweeter than honey, and so on" (The Economist, 14 May 2011). According to Stockholm International Peace Research Institute, Pakistan is China's biggest arms buyer, accounting for nearly $47 \%$ of Chinese arms exports (Wezeman, 2013). According to a 2014 BBC World Service Poll, 75\% of Pakistanis view China's influence positively, while only $15 \%$ expresses a negative view. In the Asia-Pacific region, Chinese people hold the third most positive opinions of Pakistan's influence in the world, behind Indonesia and Pakistan itself (BBC 3 June 2014).

\subsection{New Era of Pak-China Relations}

The relationship between Pakistan and China were mostly limited to the political sphere. There were frequent exchanged visits of leadership of both countries to one another. Both countries supported each other on domestic 
issues, as well as on regional and international issues. The Foreign Offices of both countries kept close coordination, which resulted in a complete harmony on international affairs (Conflict and Peace Studies, 2014). We made big strides in bilateral ties and many MoUs were signed between the two countries, with the launch of 'One Belt One Road' (OBOR) initiatives and the signing of the China-Pakistan Economic Corridor (CPEC). Hence, Pakistan and China entered a new era in their relationship. In addition to the already strong political and military relationship, economic relations have improved exponentially (Summers, 2016). Chinese investments are pouring into Pakistan, and several mega projects have been launched in power generation and transmission. Basic infrastructures like motorways, railways, airports, seaports, oil and gas pipelines, and optical fibre linkages are being upgraded and strengthened (Irshad, 2015).

\subsection{China, Seato, and Pakistan}

Even while Pakistan struggled with the awesome problem of their national survival, during the year following their independence, she watched with some concern the civil war in neighboring China. Pakistan welcomed the end of that war and the emergence of a central government, despite the presence of communist write-ups throughout China. Pakistan thought that the new posture of China, a great Asian nation rising from under a long and ruthless foreign domination, augured well for Asia. Pakistan established diplomatic relation with the new Chinese government without waiting for other state to do likewise. China was not only a neighbor but it contained a large Muslim population (Syed, 1974).

\subsection{Muhammad Ali Bogra and Chou En-lai: Towards a Better Understanding}

Personal contacts between prime Minster Mohammd Ali Bogra of Pakistan and Premier Chou En-lai of China at Bandung went a long way toward improving the tone of Sino-Pakistan relation. It is clear that Bogra went to Bandung with an open mind and a modicum of good will towards China (Rather, 2005). On this overall climates, India-China relations were technically at their best, following the Hindi-China-Bhai phase and the resultant pronouncement of India acceptance of the Chinese stance over Tibet. During this phase, Pakistan had fought one border war with India in 1948; it had inherited the Kashmir with dispute and was in search of enhanced, secure, and intimate relations with a strong country or an ally, which could help it in times of crisis (Malone \& Mukherjee, 2010). After the 1960s, Pakistan had strongly favored China's permanent seat in the UN and tried to set pace for brisk and cordial relations with it. This is attributed to the overwhelming security environment it found itself in and its lack of success in gearing multi- 
lateral diplomacy to motivate India to resolve its differences with Pakistan (Arif, 1984).

\subsubsection{The Second Phase: 1960-1970}

This period saw the disenchantment of Pakistan with the west and the increased propensity of trouble from India (Syed, 1974). China was confronted during this period with a two-pronged threat in its disenchantment with the Soviet Union and the changing relations. After the 1962 India-China war, Pakistan immerged on the south Asian scene as an ally and friend of China, as a result of the west's increased help to India during the China war and its insistence that Pakistan must help India in its China war (Javaid \& Jahangir, 2015). Pakistani and Chinese national flags and huge placards affirm SinoPakistani “friendship”. Foreign minister Chen Yi, significantly observed: we would like to point out that those who tried to isolate and blockade China have failed (Aycan et al., 2000; Dyakonov, 2015). China offered Pakistan an interest free loan of 50 million dollars and called for greater economic cooperation (Siddiqui, 2017).

\subsubsection{0's The Formative Phase}

In 1969, Nixon visited Pakistan and expressed the wish to pursue a policy of engagement with China. He asked Pakistan's President, Yahiya khan, to act as a courier between Beijing and Washington in order to inquire about China's view in the normalization initiative suggested by the Nixon's administration (Kornberg \& Faust, 2005). The mission was to be carried out with utmost secrecy, devoid of normal diplomatic channels (Kornberg \& Faust, 2005). One of the reasons cited for Nixon's decision to use Yahya khan had sprung from the fact that Pakistan was one of the few non-communist countries, which had friendly and cordial relations with the PRC (Kornberg \& Faust, 2005).

\subsubsection{The Post-Cold War Settings: 1990s}

Since the beginning of Deng Xiaoping's reforms process, China's primary task had been the pursuing of security environment which is favorable to the country's economic construction. From 1952 to 1998, China's GDP grew at an average rate of $7.7 \%$ which was much higher than the average. In tune with the post-cold-war dynamics, China's South Asian Policy went through the necessary re-adjustment in an attempt towards India-China normalization. However, defining this trend of the India-China relations was not fundamental in defining the Pak-China relations in the post-war settings. With the end of the Cold-War, Pak-US relations went through a metamorphic change. The US stopped all assistance to Pakistan in 1990 on the pretext that the country was developing a nuclear capability. The address of Chairman Li- 
pen during his visit to Pakistan on April 10, 1999, clearly defined the extensive consensus of both states on further development of China-Pakistan friendship and on international and regional issues of mutual interest (vice chairperson 1999).

A) As a result of China's experience with imperial power, it believes that it will be possible to secure peaceful international environment and avert a New World Order (Chen, 1993).

B) China opposes all hegemonic policies and power politics.

C) It seeks to persuade an independent foreign policy based on the principle of peaceful co-existence and the UN system.

D) Protection of its rights with its own territory, space, and territorial waters. Pakistan also maintained the defense of its sovereignty as an essential component of foreign policy.

E) The settlement of dispute through peaceful means.

F) The purpose of military buildup for natural defense and for external expansion (Maier, 1990).

\subsubsection{Hindi-Chini Bhai, 1950s}

The earliest phase of the Indio-China relations was one of Cordiality. Soon after the forging of diplomatic relations, India and China not only shared similar or identical views on series of major international issues, but also coordinated their efforts and cooperated effectively on many occasions for a common diplomatic struggle. For instance, China supported India in her effort to reclaim Goa, and India backed China's bid to get a permanent seat in the United Nations. During the Korean war, India opposed the UN resolutions declaring China as an aggressor. She also helped China to pass a warning to the United States, a move that grew out of China's trust in India (Tanner \& Feder, 1993).

\subsection{Sino-India Border Dispute of 1962: Its Effect on Bilateral Relations}

By 1954, Tibet was by and large recognized by India as an integral part of China. However, India maintained that Tibet was a zone of influence for New Delhi, and it was to be perceived in this very context. In 1956, there were stray uprising in various parts of the Tibetan area under Chinese Control and the uprising turned into revolt in 1959. In this context, the Indian press gave expensive coverage of the spreading rebelling and openly talked about the lack of affinity between the Chinese and Tibetans (President Jian 1996)

\subsubsection{President Jiangzemin Visit and Its Ramifications}

In 1996, President Jiang Zemin visited New Delhi and the second most important agreement, relating to CBMs, between India and China was signed (Dumitrescu, 2015). The agreement on confidence building measures (CBM) 
in the military field, along the line of actual control on India-China border areas, maintained that peace and tranquility along the India China border was in the fundamental interests of the two parties and would contribute in resolving the boundary question.

The study of international relations between India and Pakistan is dominated by different variables such as conflicts, mistrust, antagonism, crisis, and cooperation. It is not difficult to underline or locate these areas because both were cultured socially, and were politically linked before they emerged on the world scene of independent sovereign state in August 1947. History and geography played a part in designating a nation's friends from its enemies. In Pakistan's case, India has filled the enemies' role during the last half century. The Hindu of the sub-continent has born a thousand years of subjugation, and the Muslim have been victims of foreign domination. They are yet to find their bearing as independent nation and they still need to acquire confidence to break ties with the past (Lodhi, 2013). The trouble between India and Pakistan actually began even before they were established as free and independence nations.

After the partition, Indian leaders were of the opinion that Pakistan would collapse sooner or later (Hasan, 1951). They were convinced that she would not be economically viable and that the Muslims have administrative capacity. Hence, when it would collapse, they thought they would have the Muslim of Pakistan as well as those of residuary India in the bag. Indeed, they did everything to bring about the collapse of Pakistan (Husain et al., 2006). Nevertheless, efforts were made in India to correct every conceivable difficulty for Pakistan and to endanger her existence. These efforts have led to the persecution of Indian Muslims. First and foremost issue for Pakistan after partition was its survival, which was highly threatened by India. Pakistan was termed by most Indian leaders as a tragic mistake, which might still be corrected. It was their hope that it would collapse by itself, and it was their move to assist this plan (Choudhury, 1975). This sense of insecurity pushed Pakistan into the western sponsored defense alliance SEATO and CENTO as her attempt to attain party with India and as challenge to the natural power hierarchy in the sub-continent. Westad (2005), in addressing the political committee of the conference, declared that he and Pakistani prime minster had reached an understanding of "collective peace and cooperation". Pakistan would not support any aggression that the U.S might launch China under the SEATO treaty, and she neither opposed China nor appended aggression from her. By now, China's policy toward the smaller nation in the context of superpowers hegemony began to crystallize. By 1965, Pakistan became a focal point of China's new approach in international problems. The government too was alive to the danger of massive military aid to India. Mohammad Ali, 
External affairs Minister of Pakistan, took up the matter with President Kennedy and Mr. Macmillan when he saw them in October 1962.

\subsubsection{China and the Indo-Pakistan War of 1965}

In August 1965, sporadic fighting broke out between India and Pakistan in Kashmir. Then on the morning of September 6, 1965, the Indian army invaded West Pakistan, directing its attack at Lahore. Some took sides with Pakistan's allies. Iran and Turkey were sported vigorously and also others, such as Jordan, Syria, Saudi Arabia, and Indonesia. However, of all Pakistan's Supporters, China spoke the loudest. By linking the Sino-India and Indo-Pak conflicts, the Chinese fostered a sense of urgency among the powers about terminating the Indo-Pakistan war. They asserted that India's attack on Pakistan and her "intrusion" into Chinese territory were all part of the same Indian deign of aggressive expansionism (Brines, 1968).

The Chinese government, sternly condemned India for its criminal aggression, expresses firm support for Pakistan in its just struggle against aggression and solemnly warn the India government that it must bear responsibility for all the consequences of its criminal and extended aggression. India is in this case the aggressor and Pakistan is the victim. Similar expressions of support for Pakistan and condemnations of India continued to issue from Beijing until well after cease-fire line. All on the Pakistani side, but on none of these occasions had the UN Security Council uttered a "single word of disapproval”. It becomes active only when Pakistan hit back on September. This shows that the United Nations partiality for India has long history. The United Nations, consistently reversing right and wrong and calling back white has always served the interests of aggressors; it is again siding with the aggressor on the Kashmir issue and Indio-Pakistan conflict. Premier Chou Enlai, in his speech at the North Korean embassy, declared that Indian government "could not have engaged in such a serious military adventure without the consent and support of the United States” (McDougal \& Goodman, 1966).

The Chinese government pursued a policy of non-involvement by maintaining that it should be settled by the Kashmiris themselves. Just as the United States, the modern revisionists and the U.S controlled the United Nations. Beijing kept up the presser on Delhi. A note dated September 20th, following within the hours of the second ultimatum, posted fresh Indian violations of Chinese territory. The Chinese dismissed the Indian charges as fantastic tale and Pakistani spokesman described them as sheer propaganda designed to agitate certain section of opinion in the United States. In a television interview with the American Broadcasting Corporation, Pakistan's ambassador in Washington declared that there have been no promise and no collusion of any kind between my Government and China. 


\subsubsection{Tashkent Agreement-Chinese Perceptions}

Pakistan and China formally ended their war when president Ayoub Khan and prime Minister Shari made a peace settlement, following a series of meeting in the Uzbek city of Tashkent in January 1966. In this connection, it is noteworthy that the Chinese maintained a degree of military presser on the borders of Sikkim, Bhutan, and the North Frontier Agency. Several months followed the Indo-Pakistan cease-fire with a view to strengthen Pakistan's position vis-à-vis India. The United States and Soviet Union had backed India against Pakistan and made a common cause against China in pursuing their interventionist policy in South Asia. The Russian were no friends of Pakistan. Reacting to the suggestions that the Ayub government had been unnerved by the vigor of Chinese diplomacy during the war, they insisted that SinoPakistan friendships was not merely a matter of relations between the two government but extended to the two parties. They urged Pakistan to stand firm in face of Indian pressure.

\subsubsection{Indo-Pakistan War, 1971: Diplomacy of China}

The outbreak of the East Pakistan crisis in March 1971, gave rise to certain political issues of international importance such as those of separatism, East Pakistan displaced persons, foreign intervention and external armed aggression. These issues because of their serious nature and repercussion on the situation in the subcontinent had to be considered by China, or any other country in the light of its foreign policy objective. Therefore, the nature and extent of China's support to Pakistan during the crisis and the ensuing war must be considered in the light of these issues and the relative's Chinese stance towards them (Chakma, 2012).

The Chinese official attitude towards the crisis and the issues arising out of it was first made public on April 12, through a message by Mr. Chou En-Lai to president Yahya Khan. A close study of this letter shows the Chinese point of view regarding the crisis namely: (1) That China considered the happening in Pakistan as purely internal affair which should be settled by the Pakistani people without foreign intervention; this adherence to nonintervention could also be seen in China's protest note to India of April 6, 1971, (2) that China opposed the separatists as was reflected in the expression that the unification of Pakistan and the unity of the people of East and west Pakistan are the basic guarantees for Pakistan's prosperity and strength, (3) that China's firm support to Pakistan was the assurance of it (the Indian expansionists dare to launch aggression against Pakistan), (4) the US decision to top the supply of arms to Pakistan with effect from 25 March, 1971; and the revocation on 8 November license for the export of 3,600,000 dollars' worth of military equipment had widened the existing military imbalance between India and Pakistan. While massive Russian arm supply to India continued, the 
situation of Pakistan was in need of strong diplomatic and military aid. China was the only country which was able to provide arms and to whom Pakistan could turn to with confidence and would not be disappointed. China will resolutely support the Pakistan government and people in their just struggle to defend their state sovereignty and national independence.

\subsection{Two Aids Bilateralism: A Quest for Normalization 1971-2000}

Beijing's policy in south Asia during the 1970s has reflected a largely successful effort to expand relation in the region and to counteract the heavy Soviet influence. The crisis of 1977 in East Pakistan led to the Indian-Pakistani war which prompted a severe downturn in China's influence in south Asia later that year. India, which had long been hostile to China, aligned more closely to the Soviet Union in August 1971 by a Soviet-Indian friendship treaty. Pakistan, which in the past had helped China to check Indian and Soviet influence in South Asia, was split in two. The former eastern wing-Bangladesh decidedly adopted pro-Indian and Pro-Soviet policies. Over the next three years, Beijing adopted a low posture. Although China did what it could to assist Pakistan, Beijing has little alternative but to observe event happening outside, hoping for new opportunities. By 1974, two trends in South Asia promised to provide some new opening for Beijing. First India and Bangladesh eventually saw little utility in maintaining their hospitality toward Pakistan. Beijing's limited prospects in South Asia early 1972 were well demonstrated during the visit of President Bhutto of Pakistan to China from January 31 to February 2, 1972. Although Beijing afforded Bhutto's political support and afforded some measure of economic relief during the visit, yet there was an evident offered on both sides to let the dust settle in the South Asia while bolstering Bhutto's position during the post war period. Bhutto was accorded full honors, being hosted by Chou En-Lai and received by Mao. The visiting delegation, which includes the commanders of the Pakistani armed services, held talks with Chou, his leading associates Yeh Chien-ying and Li Hsien, PRC defense, and foreign affairs officials. Despite the strong military representation in the visiting delegation, the only reference in the communiqué to Chinese assistance was a decision to help the development of the Pakistan's economy by converting four outstanding loans into grants and deferring payment on a loan provided in 1970.

The Chinese muted their anti-Soviet polemic in deference to Bhutto's interested and concentrated their fire on the Indians during his visit in January 1972. The People's Daily editorial blistered the Soviets for supporting the dismemberment of Pakistan in the name of national liberation. As far as the question of Kashmir was covered, the Chinese joined their visitors in a joint communiqué calling for withdrawal to position which respected the cease-fire line in Jammu and Kashmir. Therefore, Chou declared Chinese support for 
"the people of Kashmir in their just struggle for the right to nation selfdetermination.” By mid-1974, the agreement between Indian and Pakistan to implement the UN resolution on returning prisoner of war and normalizing relations promoted expression of great Chinese interest in improving the relation with India and Bangladesh. At the same time, Beijing has continued to support Pakistan. Bhutto, now prime minister, retuned to Beijing from 11th to 14th May 1974, and the Chinese gave him the same full honour shown during his visit in early 1972. Teng Hsiao-Pring's banquet speech on UN resolution of 1971, stressed that these "New developments" had created favorable condition for normalizing relations among the countries in the subcontinent. Focusing on Beijing's own intention, Teng went beyond the usual Chinese affirmation of friendship with the People of the region, asserting that Beijing was now ready to develop relation with the countries on the subcontinent based on the five principle of peaceful co-existence.

On September 3, 1974, the People's daily article under the byline commentator offered an authoritative criticism of Indian's policy toward Sikkim. It denounced the Indian government proposal of August 1974 for a constitutional amendment to give Sikkim a status similar to that of an Indian state as a "flagrant" act of colonist Expansion. Also they alleged that reducing Sikkim to an Indian-Colony was nearly part of India's long standing design to become a "super power" and to lord it over South Asia. Making a rare reference to past Indian territorial aggrandizement fostered by Nehru, the article went on to accuse Indra Gandhi's regime of going even further along the expansionist road, citing its use of India's atomic test earlier that year to engage in nuclear blackmail.

More importantly was India's relations with Washington that had not been cordial, and their relations with Beijing have remained frozen. So, India made bids to restore full diplomatic relation with Beijing. India was still attaching great importance to Moscow's help, particularly of its military supplies, and was not happy over Beijing continued support to Pakistan. Yet, the Indian, as pointed out earlier, wants a wilder diplomatic option for the Chinese. Some dent in the Moscow-New Delhi entente would be a great diplomatic feat. It was reported in the India parliament on August 20, 1975, that there had been no anti-Indian propaganda by the Chinese in recent month. Chinese scientists took a week-long study tour of different enterprise and research and development centers in exploring prospects for increased trade with China as commerce between the two counties have declined sharply since 1962. By this time, China has emerged to the status of recognized participant in the global system, having regained its permanent seat in the security Council in 1971, in which Pakistan played a major role (Bjola \& Kornprobst, 2018). 


\subsection{China and South Asia in the Post-Mao Era}

The passing away of Mao Zedong in 1976 led to the ascendancy of Deng Xiaoping, following a brief interlude under Hau Guofeng that marked the transition. The Dengist period, which still continues, has been characterized by two dominant trends, which reflected the new leader's preoccupation with one fundamental objective: raise China from poverty and the result weakness to prosperity and strength. This reflects the aspirations of the Chinese people to have a standard of living comparable to those affluent counties of the west, and to see their counties attain the stature the "Middle Kingdom” enjoyed in its heydays in history (Maqbool Ahmed bhatty 1994).

\subsection{The Dengist Approach Manifested Itself in Two Ways}

a) Internally, the highest priory was given to the four modernization i-e agriculture, industry, Science and technology, and defense.

This produced two bisect in China's foreign policy, opening to the outside world, and it also promoted an international environment of peace and stability through negotiations (Maqbool Ahmed bhatty 1994).

b) There was early realization by China that the Soviet Union was determined to encircle and isolate it, just as the concept of Asia collective security advanced by Moscow had the same objective. China, therefore, attached primacy to improving its security situation viz-a-viz South Asia. Apart from strengthening relations with Pakistan and other countries of the region, special efforts were made to improve relations with India. Zhao-Rajeev meeting in New York October 1985 was reported to have set the tone for a constructive agreement. After the meeting, the pressmen were advised on behalf of both leaders that the Sino-Indian dispute would settle at "political as well as official level" and that effort would not be allowed to bogged down in bureaucratic hassles (Ahmed, 1992).

\subsection{Impact of the Afghanistan Crisis}

During the period, China was seeking to promote an international environment conducive to the pursuit of its economic goals. Moscow increased its expansionist activity from political support to pro-Soviet group in third world countries (Ahmed, 1992) (Angola, Ethiopia, south Yemen). This led to indirect military intervention in Cambodia through Vietnam, and finally through direct military intervention in Afghanistan as being a part of the Soviet strategy to isolate them. Thus, it is regarded as a particularly provocative move in this context. The Chinese attitude towards the major counties of South Asia was determined on the basis of their stance on the Afghanistan crisis. Chinese military assistance to Pakistan in various projects such as the setting up of the heavy rebuilding factory to overhaul, Type 59 tanks, F-6 rebuilding factory and the overhauling ability, in addition to other projects like Mbt-2000 Al- 
Khalid tank, Karakarom-8 trainer, Super 7-fighter jets etc. were time and again projected as a potent threat to India (Yuan, 2007).

\subsection{Sino-Indian Rapprochement}

The visit of Prime Minister Rajiv Gandhi to China in December 1988 marks the first contact at the head of government level between the two countries after 1960, when Premier Zhou En-Lai had visited India. This visit also reelected "advice” by Gorbachev to India to mend its fences with China (Maqbool, Ahmed Bhstty).

\subsection{The Working Dynamic of the Straddle Triangle 1910}

The end of the cold war brought a noticeable de-escalation in the level of tension in numerous conflicts in the third world (Navnita, Chacha \& Behern, 1946). The reduced presence of the erstwhile Soviet Union and Russia had contributed to lowering of tensions and the intensity of rivalry between the sub regional sectors. International security theorists argue that the rational sources of securities and threat had been replaced with non-traditional sources of security namely economic development, environmental security, and human development. The states of inertia, which had marked the IndianPakistan relationship for the last four decades till 1990s, saw a rapid increase of tension and hostility with a massive uprising in Kashmir's freedom struggle in 1998. The unprecedented tension led to the nuclear crisis of 1990s, when both sides had reportedly prepared their weapon systems for a possible exchange. South Asia's core regional conflict is that which exists between India and Pakistan, although it is perceived by the India-China threat perception, which is structurally different and does not relate to the same degree of interaction that characterize India-Pakistan rivalry (Chari, Cheema, \& Cohen, 2009).

\subsection{Impacts of Nuclear Tests of May 1998}

The formation of a BJP-led government in India following the elections of March 1998 produced a significant change in New Delhi's perceptions and goals. The militant Hindu leadership proceeded to implement its agenda, in which open weapons of India's nuclear capability was on top. In an obvious move to garner western approval to this move, Indian defense minister, George Fernandez, in an interview with the BBC in April 1998 (within a month of his assuming office) said that China posed a greater threat to Indian security than Pakistan. Addressing a meet-the press session in New Delhi, Fernandez accused the Chinese of frequent intruding into Indian Territory and constructing a help in Raunchily Pradesh. 


\subsection{Conclusion}

The purpose of this research was to view the impact of the developments within the ambit of relations amongst the three major players in the south Asia, namely; India, Pakistan, and China from 1974 to 2000. China's pragmatic approach in its foreign relations, Sino-Indian rapprochement, and end of cold war was viewed as an era of transition, ultimately paving the way for future global power configuration. Hence, the need arose to analyze the effect of the movement on international relations, in the face of the rapid change in the international system. Underlying emphasis on factors like globalization and free market economy, it was necessary to see how far the international trends had transcended the mutual relations of Pakistan, India and China. Hence, this is a bi-product of super power policy of engagement and inter-sate relations and mix of regional power politics.

Pakistan's overall perspective on foreign policy has been determined by the threat it had faced since independence from its much large neighbor, India. The threat which is derived from the hegemonic impulse of the second largest country in the world, and the rejection by it, is elite to the very basis on which Pakistan emerged. Hence, it compels Pakistan to pursue political design to safeguard its security and survival. In this context, the foreign policy of China, the only great power that has borders with South Asia, is of critical importance. Recognizing India as one of its major strategic rivals, China has since 1963 aligned itself with Pakistan to continue the common threat. Critics argue that Beijing's policy towards the sub-continental rivals has been based on the classic threat perception and strategic thinking. This was despite China's efforts to justify its political and military links with Pakistan as normal state-to-state relations.

Pak-China relations since their inception have been based on solid foundations and are likely to remain poised in the future as an all-weather relationship. The mutuality of interests is such that neither side can forego the benefits of the relations to either state. From a Chinese foreign policy perspective, conflict and war are counter-productive. Thus, China's indulgence into such an activity at this time in history could and can delay its rise to world great power. On the other hand, an improved state of Sino-Indian relations would and can also inadvertently raise the stake for China, amidst increasing Indo-US collaboration and the potential of India to use China as a means to justify its own rise to great power status. Hence, in the contemporary phase, the relationship of rivalry between the two states and that of friendship and strategic schism was in a bid to counter balance the Indian movement and her leverage in Beijing's central affairs. Thus, China requires a strong foothold in South Asia. 


\section{References:}

1. Ahmed Akbar, S. (1992). Bombay films: The cinema as metaphor for Indian society and politics. Modern Asian Studies, 26(2), 289-320.

2. Amar Akhil Reed (1990). The Bill of Rights as a Constitution. Yale Lj, 100, 1131.

3. Arif, K. (1984). China Pakistan Relations, 1947-1980: Vanguard Books.

4. Arif Muhammad \& Mahmood Khalid (2012). The changing role of librarians in the digital world: adoption of Web 2.0 technologies by Pakistani librarians. The Electronic Library, 30(4), 469-479.

5. Aycan Zeynep, Kanungo Rabindra, Mendonca Manuel, Yu Kaicheng, Deller Jürgen, Stahl Günter, \& Kurshid Anwar (2000). Impact of culture on human resource management practices: A 10-country comparison. Applied Psychology, 49(1), 192-221.

6. Barua Dilip, K., Kuehl Steven, A., Miller Richard, L., \& Moore Williard, S. (1994). Suspended sediment distribution and residual transport in the coastal ocean off the Ganges-Brahmaputra river mouth. Marine Geology, 120(1-2), 41-61.

7. Bjola Corneliu \& Kornprobst Markus (2018). Understanding international diplomacy: theory, practice and ethics: Routledge.

8. Brecher Michael (1963). International relations and Asian studies: the subordinate state system of Southern Asia. World Politics, 15(2), 213235.

9. Brines Russell (1968). The Indo-Pakistani Conflict: Pall Mall P.

10. Brzezinski Zbigniew (2012). Strategic vision: America and the crisis of global power: Basic Books.

11. Buzan Barry \& Segal Gerald (1994). Rethinking East Asian Security. Survival, 36(2), 3-21.

12. Chakma Bhumitra (2012). Pakistan's nuclear weapons: Routledge.

13. Chari Padmanabha Ranganatha, Cheema Pervaiz Iqbal, \& Cohen Stephen, P. (2009). Four crises and a peace process: American engagement in South Asia: Brookings Institution Press.

14. Chaudhri Mohammed Ahsen (1987). Geopolitical Factors in PakistanIndia Relations. Pakistan Horizon, 40(1), 30-50.

15. Chen Qimao (1993). New Approaches in China's Foreign Policy: The Post-Cold War Era. Asian Survey, 33(3), 237-251.

16. Choudhury Golam Wahed (1975). India, Pakistan, Bangladesh, and the major powers: politics of a divided subcontinent: Free Press.

17. Dijink Gertjan (2002). National identity and geopolitical visions: Maps of pride and pain: Routledge. 
18. Douglas Mary \& Wildavsky Aaron (1983). Risk and culture: An essay on the selection of technological and environmental dangers: Univ of California Press.

19. Dumitrescu Lucian Tefan (2015). Security Imaginary. A New Perspective on Security Identity and Ethnic Violence. ROMANIAN REVIEW OF POLITICAL SCIENCES AND INTERNATIONAL RELATIONS, 1.

20. Dyakonov Severyan (2015). Soviet cultural diplomacy in India, 19551963. Concordia University.

21. Fisher Roger, Ury William \& Patton Bruce (2011). Getting to yes: Negotiating agreement without giving in: Penguin.

22. Forman Geremy \& Kedar Alexandre (2004). From Arab land to 'Israel Lands': the legal dispossession of the Palestinians displaced by Israel in the wake of 1948. Environment and Planning D: Society and Space, 22(6), 809-830.

23. Ganguly Šumit (2002). Conflict unending: India-Pakistan tensions since 1947: Columbia University Press.

24. Ganguly Šumit \& Hagerty Devin, T. (2012). Fearful symmetry: IndiaPakistan crises in the shadow of nuclear weapons: University of Washington Press.

25. Garver John, W. (1996). Sino-Indian Rapproachement and the SinoPakistan Entente. Political Science Quarterly, 111(2), 323-347.

26. Garver John, W. (2011). Protracted contest: Sino-Indian rivalry in the twentieth century: University of Washington Press.

27. Gupta Akhil (1998). Postcolonial developments: Agriculture in the making of modern India: Duke University Press.

28. Haqqani Husain (2010). Pakistan: Between mosque and military: Carnegie Endowment.

29. Hasan Sarwar, K. (1951). The Foreign Policy of Mr. Liaquat Ali Khan. Pakistan Horizon, 4(4), 181-199.

30. Hemmer Christopher \& Katzenstein Peter (2002). Why is there no NATO in Asia? Collective identity, regionalism, and the origins of multilateralism. International organization, 56(3), 575-607.

31. Hilali, A.Z. (2002). Pakistan's nuclear deterrence: Political and strategic dimension. Department of Politics, Centre for Security Studies, University of Hull, UK.

32. Husain, N., Bevc, I., Husain, M., Chaudhry, I.B., Atif, N., \& Rahman, A. (2006). Prevalence and social correlates of postnatal depression in a low income country. Archives of women's mental health, 9(4), 197202.

33. Hussain, Syed Shahbaz, Javaid, Umbreen, Sabri, Pirzada Sami Ullah, Ilyas, Muhammad, \& Batool, Iffat. (2014). Compulsions of Sino- 
Pakistani Strategic Engagement in lieu of Security Constraints Engendered by the Anarchistic International Political System. South Asian Studies, 29, 2.

34. Hussain Touqir (2015). Kashmir dispute. Regional and Ethnic Conflicts: Perspectives from the Front Lines, CourseSmart eTextbook, 41.

35. Irshad Muhammad Saqib (2015). One belt and one road: dose ChinaPakistan economic corridor benefit for Pakistan's economy?

36. Jalal Ayesha (1995). Democracy and authoritarianism in South Asia: A comparative and historical perspective (Vol. 1): Cambridge University Press.

37. Javaid Umbreen \& Jahangir Asifa (2015). Pakistan-China Strategic Relationship: A Glorious Journey of 55 Years. Journal of the Research Society of Pakistan, 52(1).

38. Joshi Puran Chandra (1974). Land reform and Agrarian change in India and Pakistan since 1947: 1. The Journal of Peasant Studies, 1(2), 164-185.

39. Kiernan, V.G. (1976). China and Pakistan: Diplomacy of an Entente Cordiale: Oxford University Press.

40. Kornberg Judith, F. \& Faust John, R. (2005). China in world politics: policies, processes, prospects: UBC Press.

41. Lamb Alastair (1966). Kashmir Problem: Praeger New York.

42. Lavoy Peter, R. \& Lavoy Peter René (2009). Asymmetric warfare in South Asia: the causes and consequences of the Kargil Conflict: Cambridge University Press.

43. Lerski George, J. (1968). The Pakistan-American alliance: A reevaluation of the past decade. Asian Survey, 8(5), 400-415.

44. Lodhi Iftikhar, A. (2013). Pakistan: Perceptions and Responses of an All-weather Friend A Resurgent China (pp. 186-222): Routledge India.

45. Maier John, H. (1990). " Tian'Anmen 1989": the View From Shanghai. China Information, 5(1), 1-13.

46. Malone David, M. \& Mukherjee Rohan (2010). India and China: conflict and cooperation. Survival, 52(1), 137-158.

47. McDougal Myres, S. \& Goodman Richard, M. (1966). Chinese Participation in the United Nations: The Legal Imperatives of a Negotiated Solution. American Journal of International Law, 60(4), 671-727.

48. Mishra Keshav (2004). Rapprochement Across the Himalayas: Emerging India-China Relations Post Cold War Period (1947-2003): Gyan Publishing House. 
49. Mukherjee Anit (2009). A brand new day or back to the future? The dynamics of India-Pakistan relations. India Review, 8(4), 404-445.

50. Norbu Dawa (1997). Tibet in Sino-Indian relations: The centrality of marginality. Asian Survey, 37(11), 1078-1095.

51. Pande Aparna (2011). Explaining Pakistan’s foreign policy: escaping India: Routledge.

52. Perkovich George (2002). India's nuclear bomb: the impact on global proliferation: Univ of California Press.

53. Rajain Arpit (2005). Nuclear Deterrence in Southern Asia: China, India and Pakistan: SAGE Publications India.

54. Rashid Ahmed (2008). Descent into chaos: the US and the failure of nation building in Pakistan, Afghanistan, and Central Asia: Penguin.

55. Rather Mushtaq Ahmad (2005). Sino-Pak Strategic Collaboration and its Impact on India's Security. Aligarh Muslim University.

56. Ray Raka \& Qayum Seemin (2009). Cultures of servitude: Modernity, domesticity, and class in India: Stanford University Press.

57. Rizvi Hasan-Askari (1993). Pakistan and India: Divergent Goals and Bilateral Relations Pakistan and the Geostrategic Environment (pp. 1849): Springer.

58. Sachs, Jeffrey D, Warner, Andrew, Åslund, Anders, \& Fischer Stanley (1995). Economic reform and the process of global integration. Brookings papers on economic activity, 1995(1), 1-118.

59. Saini Saroj (2014). China's strategic interests in Gilgit Baltistan-Its implications on India. International Journal of Physical and Social Sciences, 4(4), 522.

60. Schofield Victoria (2010). Kashmir in conflict: India, Pakistan and the unending war: IB Tauris.

61. Shambaugh David (2000). China's military views the world: ambivalent security. International Security, 24(3), 52-79.

62. Siddique Qandeel (2014). Deeper than the Indian Ocean? An Analysis of Pakistan-China Relations. Center for International and Strategic Analysis Report No, 16.

63. Siddiqui Salman (2017). Pakistan will be paying China $\$ 90$ b against CPEC-related projects. The Express Tribune, 12.

64. Sisson Richard \& Rose Leo, E. (1991). War and secession: Pakistan, India, and the creation of Bangladesh: Univ of California Press.

65. Smith Donald Eugene (2015). India as a secular state (Vol. 2231): Princeton University Press.

66. Summers Tim (2016). China’s 'New Silk Roads': sub-national regions and networks of global political economy. Third World Quarterly, 37(9), 1628-1643. 
67. Syed Anwar (1969). Sino-Pakistan Relations-An Overview. Pakistan Horizon, 22(2), 107-119.

68. Syed Anwar Hussain (1974). China \& Pakistan: diplomacy of an entente cordiale: Univ of Massachusetts Press.

69. Talbot Ian (2010). India and Pakistan Routledge Handbook of South Asian Politics (pp. 43-56): Routledge.

70. Tanner Murray Scot \& Feder Michael (1993). Family politics, elite recruitment, and succession in Post-Mao China. The Australian Journal of Chinese Affairs(30), 89-119.

71. Tellis Ashley, J. (2001). India's emerging nuclear posture: Between recessed deterrent and ready arsenal (Vol. 1127): Rand Corporation.

72. Tellis Ashley, Fair Christine, \& Medby Jamison Jo (2002). Limited conflicts under the nuclear umbrella: Indian and Pakistani lessons from the Kargil crisis: Rand Corporation.

73. Thomas Raju, GC. (1981). Security Relationships in Southern Asia: Differences in the Indian and American Perspectives. Asian Survey, 689-709.

74. Tudor Maya (2013). The promise of power: The origins of democracy in India and autocracy in Pakistan: Cambridge University Press.

75. Varshney Ashutosh (2003). Ethnic conflict and civic life: Hindus and Muslims in India: Yale University Press.

76. Westad Odd Arne (2005). The global Cold War: third world interventions and the making of our times: Cambridge University Press.

77. Yuan Jing-dong (2007). The dragon and the elephant: Chinese-Indian relations in the 21st century. Washington Quarterly, 30(3), 131-144.

78. Zhisheng An, Tunghseng Liu, Yanchou Lu, Porter SC, Kukla GHWX, Xihao Wu, \& Yingming Hua (1990). The long-term paleomonsoon variation recorded by the loess-paleosol sequence in central China. Quaternary International, 7, 91-95. 